\title{
XRN1 wt Allele
}

National Cancer Institute

\section{Source}

National Cancer Institute. XRN1 wt Allele. NCI Thesaurus. Code C94706.

Human XRN1 wild-type allele is located in the vicinity of 3q23 and is approximately $141 \mathrm{~kb}$ in length. This allele, which encodes 5'-3' exoribonuclease 1 protein, is involved in the regulation of both RNA processing and mRNA stability. 